\title{
DAMPAK KEDISIPLINAN DAN MOTIVASI KERJA TERHADAP KINERJA ASN DI PEMERINTAH KABUPATEN GUNUNG KIDUL
}

\author{
Risma Nur Avita ${ }^{1}$, Soffy Balgies ${ }^{2}$, Achmad Willyansyah Ahyaturraja ${ }^{3}$ \\ 1,2,3 Universitas Islam Negeri Sunan Ampel Surabaya \\ nuravitarisma@gmail.com
}

\begin{abstract}
ASN is a state apparatus in charge of implementing all existing policy steps within government agencies. The functions of the ASN or State Civil Apparatus include: as an implementer of public policy, as a public service in society, as well as as an adhesive and unifier of the nation. However, in carrying out their duties, civil servants were still found violating their work discipline. So, the application of work discipline in agencies needs to be considered. Because work discipline has a significant influence on employee performance. Work discipline is a process of assessing or correcting and giving punishment to subordinates for violating a rule or procedure. The application of work discipline includes imposing sanctions for those who break discipline. In addition, work motivation also affects employee performance in carrying out predetermined tasks. Where motivation is a factor that can support a person in carrying out a certain activity or activity, where every activity carried out by someone must have a stimulus. This includes giving rewards to employees who have reached a predetermined limit, providing adequate facilities, providing social security, etc.
\end{abstract}

Keywords: Work Discipline, Work Motivation, Performance, ASN

\begin{abstract}
ABSTRAK
ASN merupakan aparatur negara yang bertugas melaksanakan segala langkah kebijakan yang ada dalam instansi pemerintah. Adapun fungsi dari ASN atau Aparatur Sipil Negara diantaranya adalah: sebagai pelaksana kebijakan publik, sebagai pelayanan public di masyarakat, serta sebagai perekat dan pemersatu bangsa. Namun dalam melaksanakan tugas masih ditemukan ASN yang melanggar kedisplinan kerja. Maka, penerapan kedisiplinan kerja dalam instansi perlu diperhatikan. Karena kedisiplinan kerja mempunyai pengaruh yang cukup signifikan terhadap kinerja pegawai. Kedisiplinan kerja merupakan sebuah proses menilai atau mengkoreksi serta memberikan punishment kepada bawahan jika melanggar sebuah aturan atau prosedur. Penerapan kedisiplinan kerja tersebut mencakup pemberian sanksi bagi pelenggar kedisiplinan. Selain itu, motivasi kerja juga berpengaruh terhadap kinerja pegawai dalam melaksanakan tugas yang telah ditentukan. Dimana motivasi adalah faktor yang dapat menunjang seseorang dalam melakukan sebuah aktivitas atau kegiatan tertentu, dimana setiap aktivitas yang dilakukan oleh seseorang harus memiliki sebuah stimulus. Hal tersebut meliputi pemberian reward pada pegawai yang sudah mencapai batas yang yang telah dotentukan, memberikan fasilitas yang memadai, memberikan jaminan sosial, dll.
\end{abstract}

Kata Kunci: Kedisiplinan Kerja, Motivasi Kerja, Kinerja, ASN

\section{Pendahuluan}

Kelancaran tugas pemerintahan atau pembangunan nasional tergantung pada aparatur sipil negara (ASN). Untuk mencapai tujuan utama pembangunan nasional, yaitu mewujudkan masyarakat yang beradab, taat hukum, demokratis, adil, makmur, dan menjunjung tinggi akhlak, diperlukan aparatur sipil negara. Yang pekerjaannya sebagai abdi negara atau abdi masyarakat. Fungsi ASN adalah sebagai aparatur negara yang bertugas memberikan pelayanan yang sebaik-baiknya kepada masyarakat, yang dilaksanakan secara profesional, jujur, adil dan tanpa pandang bulu dalam melaksanakan tugas tersebut. Hal ini juga dilandasi kesetiaan dan ketaatan terhadap UUD 1945, serta diiringi dengan sikap dan tindakan pengabdian, kejujuran, disiplin, dan tanggung jawab. Sehingga diharapkan dapat memberikan sebuah pelayanan yang sesuai dengan tuntutan perkembangan masyarakat. 
Akan tetapi tidak sedikit juga terdapat beberapa oknum ASN yang masih berani untuk melanggar peraturan ataupun melanggar kedisiplinan kerja. Jika ditemukan orang yang melanggar prosedur atau aturan kedisiplinan kerja. Maka akan diberikan sanksi yang sesuai dengan tingkat pelanggaran tersebut. Sanksi yang diberikan dapat berupa : sanksi teguran, sanksi penurunan jabatan, ataupun sanksi pemberhentian kerja.

Seperti kasus yang terdapat di Pemerintah kabupaten Gunung Kidul, bahwa telah dibuktikan terdapat sederetan kasus ASN yang melakukan pelanggaran terhadap prosedur atau aturan dalam kedisiplinan kerja. Dimana pada Pemerintah kabupaten Gunung Kidul terdapat ASN yang dipecat, dimana hal tersebut diduga karena terjerat kasus korupsi. Kemudian, ada juga ASN sebanyak enam orang yang diberikan sanksi karena telah melakukan pelanggran terhadap prosedur yang telah ditetapkan.

Kepala Sub Bidang Status dan Kedudukan Pegawai, Badan Kepegawaian Pendidikan dan Pelatihan (BKPP) di Gunung Kidul yakni yang bernama Sunawan mengatakan dan membenarkan bahwa, pemecatan terdapat ASN yang terjerat korupsi tersebut dilaksanakan setelah terdapat keputusan hukum yang tetap. Sehingga pemkab dengan cepat tanggap melakukan tindak lanjut dengan memberhentikan atau memecat ASN tersebut yang akibat ulahnya sendiri.

Ditemukan juga sebanyak dua ASN yang mendapatkan sanksi berat yakni penurunan pangkat selama 3 tahun. Hal tersebut dikarenakan tidak masuk kerja sebanyak lebih dari 36 hari. Dan untuk ASN yang melakukan pelanggaran terhadap disiplin kerja, maka akan dikenakan sanksi berupa penurunan pangkat selama 2 tahun. Semua sanksi tersebut diberikan sesuai dengan SK dan tingkat pelanggaran yang telah dilakukan. Disisi lain juga ditemukan dua ASN yang terjaring dalam kasus perselingkuhan dan kasus foto vulgar. Dan hal tersebut juga sudah diberikan sanksi yang sesuai dengan peraturan pemerintah mengenai disiplin kerja.

Fakta mengenai kasus pelanggaran kedisiplinan kerja yang dilakukan oleh ASN di Pemkab. Gunung Kidul menjadi sebuah berita yang kurang enak didengar oleh masyarakat. Yang menyebabkan timbulnya rasa kekecewaan masyarakat terhadap ASN tersebut. Dimana yang pada awalnya, ASN sebagai aparatur Negara yang bekerja secara professional dan memberikan pelayanan public terhadap masyarakat. Namun hal tersebut tidak dapat dibuktikan dengan baik.

Menurut Sastrohadiwiryo, tujuan pembuatan sanksi-sanksi tersebut adalah untuk mengontrol, dan memberikan pendidikan atau efek jera kepada tenaga kerja yang telah melakukan pelanggaran terhadap prosedur yang telah ditetapkan. Dalam arti lain, sanksi ini bertujuan untuk memberikan arahan yang baik dan memperbaiki perilaku yang tenaga kerja yang menyimpang dari aturan. Terdapat beberapa bentuk sanksi yang diterima oleh seseorang, jika melanggar sebuah prosedur atau aturan kerja, diantaranya adalah : sanksi teguran lisan atau tertulis. Dimana dalam teguran tersebut dapat diaplikasikan sebagai : penurunan jabatan, pemindahan posisi kerja, penghentian pekerjaan, dan pengaduan kepada aparat yang berwenang (Mustika \& Susanti, 2019).

Dilihat dari pandangan E. Ultrecht yang dikutip oleh Muchsan (Sri Hartini, 2014) dalam bukunya UU Ketenagakerjaan, Negara dikatakan sebagai badan hukum yang ada melalui perkembangan faktor sosial dan politik sepanjang sejarah. Atas dasar pendapat tersebut terlihat bahwa Negara sebagai organisasi kekuasaan, yaitu badan yang berbadan hukum sebagai pembela hak dan kewajiban. Status badan hukum beserta urusan dan kewajibannya digunakan oleh negara untuk mencapai tujuan tersebut.

Hak dan kewajiban yang dilakukan oleh badan negara dialokasikan kepada kantor negara. Saat badan negara melaksanakan hak dan kewajibannya dipanggil atau disebut pejabat publik. Hubungan antara pejabat pemerintah dan negara dapat dijadikan aturan dalam undang-undang ketenagakerjaan.

Keberhasilan suatu organisasi dalam mencapai sebuah tujuan utama tersebut dapat ditentukan oleh mutu yang professional dan tingkat kedisiplinan para anggotanya. Bag aparatur pemerintahan tersebut meliputi : unsur ketaatan, loyalitas dalam melaksanakan tugasnya dan kemampuan berkorban.. Atau dalam arti lain bersedia mengorbankan kepentingan pribadi demi kepentingan Negara dan masyarakat.

Untuk mewujudkan hal tersebut, langkah yang harus diambil dan diperhatikan adalah meningkatkan tingkat kedisiplinan pegawai. Dimana disiplin yang dimaksud meliputi unsur kepatuhan terhadap prosedur kedisiplinan kerja yang telah ditentukan,dan ditentukan oleh besarnya rasa tanggung jawab dan kesanggupan dalam menjalankan tugas yang telah diberikan, serta sanggup 
menerima segala ketetapan termasuk sanksi jika terjadi pelanggaran terhadap kewajiban dan kewenangan yang berlaku.

\section{Studi Pustaka}

\section{Kedisiplinan Kerja}

Kedisiplinan kerja adalah sebuah proses menilai atau mengkoreksi serta memberikan punishment kepada bawahan jika melanggar sebuah aturan atau prosedur (Munadjat et al., 2019). Kedisiplinan kerja juga dapat diartikan sebagai fungsi terpenting dalam pengelolahan sumber daya manusia Hal ini dikarenakan semakin tinggi tingkat kedisiplinan karyawan maka semakin tinggi pula prestasi dan prestasi yang akan diraih. Disiplin tinggi dapat menunjukkan karyawan dengan rasa tanggung jawab atas pekerjaan mereka. (Suprajang, 2017).

Menurut Mangkunegara (2004: 19) pada dasarnya, disiplin merupakan sebuah kemampuan untuk mengendalikan diri dengan cara patuh atau taat terhadap prosedur yang telah dibuat, atau dalam artian tidak melakukan sebuah tindakan yang bertentangan dengan aturan yang sudah ditetapkan dan disepakati (Amiruddin, 2019).

Disiplin kerja adalah keadaan dimana tindakan seseorang yang taat dengan prosedur kerja yang ada. Disiplin kerja juga bisa diartikan sebagai alat transfer yang digunakan oleh atasan untuk berkomunikasi dengan bawahan, sehingga dengan adanya disiplin kerja diharapkan dapat mengubah perilaku atau tindakan yang menyimpang dari aturan. Hal tersebut juga dalam upaya meningkatkan kesadaran akan kepatuhan terhadap semua prosedur perusahaan dan norma sosial yang ditetapkan (Kurniawan, Harry, 2019).

Dibwah ini merupakan hal-hal yang dapat mempengaruhi kedisiplinan pegawai dalam suatu organisasi, antara lain:

a. Arah tujuan yang jelas dan kemampuan dalam menjalankan tugas.

b. Pimpinan yang memiliki sikap teladan.

c. Adanya sanksi hukum yang berlaku.

d. Adanya rasa keadilan dari pimpinan kepada pegawai.

e. Pengawasan terhadap prosedur kerja secara ketat.

f. Terdapat system balas jasa, seperti : gaji dan kesejahteraan.

g. Ketegasan dalam membuat sebuah prosedur atau aturan, serta

h. Hubungan kemanusian (Amiruddin, 2019).

Ada 2 misi penerapan disiplin kerja yakni, tujuan umum dan khusus, antara lain :

a. Tujuan umum disiplin kerja adalah untuk memelihara kesinambungan sistematik atau kebutuhan perusahaan.

b. Tujuan khusus dari disiplin kerja, diantaranya yaitu: supaya para tenaga kerja dapat menyempurnakan dan melaksanakan segala kebijakan ketenagakerjaan yang telah ditetapkan, kemudian dapat melaksanakan tugas sebaik-baiknya. Selain itu, Anda dapat memanfaatkan fasilitas dan infrastruktur perusahaan serta memeliharanya, dan pada akhirnya tenaga kerja Anda dapat mencapai produktivitas tingkat tinggi. (Suprajang, 2017).

Jadi dapat disimpulkan bahwa Disiplin merupakan sebuah upaya yang diperlukan ditegakkan untuk mencapai sebuah tujuan yang diinginkan. Oleh karena itu, disiplin kerja sangat dibutuhkan dalam sebuah perusahaan atau organisasi. Karena tujuan dari disiplin kerja adalah untuk menciptakan sebuah suasana yang efektif dalam sebuah organisasi (Tumilaar, 2015).

\section{Motivasi Kerja}

Motivasi adalah faktor yang dapat menunjang seseorang dalam melakukan sebuah aktivitas atau kegiatan tertentu, dimana setiap aktivitas yang dilakukan oleh seseorang harus memiliki sebuah stimulus. Oleh karena itu, factor yang dapat mendorong seseorang dalam melakukan sebuah aktivitas adalah kebutuhan dan keinginan terhadap sesuatu. Dengan demikian seseorang dapat termotivasi untuk melakukan aktivitas tertentu untuk mendapatkan apa yang dia butuhkan. Setiap individu memiliki keperluan serta cita-cita yang berbeda. Ini terjadi karena proses mental yang terjadi pada seseorang (Kurniawan, Harry 2019). 
Dalam pengertian lain, motivasi adalah proses atau metode untuk mencapai suatu tujuan tertentu dengan menjadi pendorong yang dibutuhkan seseorang untuk melakukan suatu kegiatan. Jika Anda bisa mencapai tujuan ini, itu akan menciptakan rasa kepuasan pribadi. (Munandar 2001).

Pentingnya motivasi serta kualitas pegawai berpengaruh terhadap peningkatan produktivitas dan kualitas pelayanan organisasi untuk mencapai sebuah cita cita utama organisasi. Konfrontasi dan tantangan bagi manajer yakni dalam menciptakan jenis motivasi yang sesuai dan cocok diterapkan kepada pegawainya (Tumilaar 2015).

Namun, apabila motivasi kerja seseorang rendah, maka unjuk kerja yang dihasilkan akan rendah. Meskipun ia memiliki peluang kerjanya ada dan mempunyai skill yang baik. Kemudian jika motivasi kerja seseorang yang tinggi, namun peluang kerja dan skill nya tidak ada. Maka unjuk kerja yang dihasilkan juga akan rendah. Sama halnya jika motivasi kerja yang besar, peluang kerja juga ada, namun tidak memiliki skill. Maka unjuk kerja yang dihasilkan juga akan rendah pula (Munandar 2001). Sehingga bisa diartikan jika motivasi sebagai kekuatan dari dalam maupun luar yang dapat membangun semangat dan keuletan seseorang untuk mendapatkan apa yang diinginkan (Tumilaar 2015).

\section{Kinerja}

Menurut Harsuko (2011), kinerja merupakan usaha yang dilakukan oleh seseorang dalam memainkan strategi organisasi, dengan tujuan mencapai sebuah sasaran khusus yang berkorelasi antara peran individu dengan memperlihatkan sebuah kemampuan atau kompetensi yang dinyatakan signifikan bagi organisasi. Atau dapat diartikan sebagai suatu konsep yang meliputi 3 aspek yakni : sikap, kemampuan dan prestasi (Rosmaini \& Tanjung, 2019).

Kinerja merupakan hasil dari tingkat keberhasilan seorang pekerja atau karyawan dalam melaksanakan suatu tugas dalam kurun waktu tertentu. Dengan perbandingan berbagai kemungkinan, seperti evaluasi standar hasil kerja, sasaran atau sasaran yang sebelumnya ditentukan oleh organisasi (Munadjat, Tumanggor, and Oktrima 2019).

Adapun manfaat kinerja dalam sebuah organisasi diantaranya, adalah :

1. Dapat memberikan arahan penting kepada pimpinan organisasi ketika mengambil keputusan di bidang sumber daya manusia. Contoh: keputusan promosi dan hubungan kerja.

2. Mengidentifikasi kebutuhan pembangunan melalui evaluasi. Kemudian Anda dapat mengembangkan dan meningkatkannya melalui program tersebut.

3. Mengetahui efektivitas pemilihan atau penempatan pegawai baru dalam program diklat.

4. Memberikan umpan balik kepada karyawan melalui perspektif organisasi terhadap kinerja karyawan.

5. Digunakan untuk alokasi reward seperti kenaikan uppah, hadiah dan reward lainnya.

Adapun faktor yang digunakan untuk mengukur tingkat kinerja pegawai, diantaranya adalah sebagai berikut:

1. Kualitas, yaitu tingkat di mana hasil dari suatu kegiatan mendekati nilai sempurna.

2. Kuantitas, Jumlah produksi yang diproduksi juga dapat dinyatakan dalam mata uang.

3. Up-to-dateness dimana suatu kegiatan dapat diselesaikan dalam waktu tertentu.

4. Efisiensi biaya, yaitu jumlah sumber daya organisasi seperti manusia, keuangan, teknologi dan bahan baku yang digunakan untuk menghasilkan keuntungan.

5. Hubungan interpersonal, yaitu derajat keterkaitan seorang pegawai yang mampu mengembangkan rasa hormat dan kerjasama antara satu pegawai dengan pegawai lainnya. (Rosmaini \& Tanjung, 2019).

\section{Aparatur Sipil Negara}

ASN adalah aparatur negara yang bertugas melaksanakan segala langkah kebijakan instansi pemerintah. Karyawan ASN tidak boleh menjadi anggota atau direktur partai politik. Hal ini dilakukan untuk menjauhkan birokrasi dari pengaruh parpol, juga untuk menjamin keutuhan dan kekompakan ASN, serta diharapkan dapat memusatkan perhatian seluruh jajarannya pada tugas-tugas yang diberikan kepadanya. (Haeli, 2018).

Adapun fungsi ASN dalam menjalankan kedudukannya tersebut, adalah berfungsi sebagai berikut, diantaranya adalah: 
1. Sebagai pelaksana kebijakan public

Dalam hal ini, fungsi ASN melaksanakan segala ketetapan yang dikembangkan oleh Personal trainer sesuai dengan ketentuan dan peraturan perundang-undangan. Untuk itu ASN harus mengutamakan kepentingan komunitas dan sosial di atas kepintingan pribadi.

2. Sebagai pelayanan publik.

Dalam hal ini, kualitas dan profesionalitas dalam memberikan layanan publik merupakkan misi ASN. Sebagaimana yang tersebut dalam peraturan erundang undangan palayanan publik adalah salah satu kegiatan dalam rangka memenuhi kebutuhan pelayanan masyarakat. Oleh karena itu ASN diharapkan dapat melayani masyarakat dengan profesional, supaya masyarakat dapat terpuaskan.

3. Sebagai perekat dan pemersatu bangsa.

Dalam hal ini ASN membantu memperkuat persatuan dan kesatuan NKRI, Negara Kesatuan Republik Indonesia senantiasa menaati Pancasila, Undang-Undang Dasar 1945, serta peraturan nasional dan pemerintahan. Selain itu, ASN diharapkan dapat menjaga harkat dan martabat Dalam UU ASN disebutkan bahwa ASN diharapkan dapat mengutamakan serta mementingkan persatuan dan kesatuan bangsa diatas segala-galanya (Haeli, 2018).

\section{Metode Penelitian}

Pembuatan artikel ini menggunakan studi literature yang bersumber pada jurnal hasil penelitian terdahulu, buku, maupun, website resmi milik pemerintah yang digunakan untuk mencari data fenomena. Dalam hal ini literature review didapatkan melalui beberapa website terpercaya, seperti: google scholar, ebsco, garuda ristekdikti, sintha, science direct, dan lain sebagianya. Menurut (Danial \& Warsiah, 2009) studi literature adalah merupakan penelitian yang dilakukan oleh peneliti dengan mengumpulkan sejumlah buku buku, majalah yang berkaitan dengan masalah dan tujuan penelitian.

\section{Hasil dan Pembahasan}

\section{Dampak Kedisiplinan Kerja Terhadap Kinerja}

Kedisiplinan kerja mempunyai pengaruh atau dampak yang signifikan terhadap kinerja ASN. Oleh karena itu, perlu adanya penegasan mengenai kedisiplinan kerja dalam organisasi. Hal ini bertujuan supaya dapat meningkatkan kinerja pegawai yang ada dalam organisasi tersebut. Dengan demikian, maka dapat dikatakan bahwa terdapat korelasi yang searah antara kedisiplinan dengan kinerja pegawai.

Strategi untuk meningkatkan kedisiplinan kerja dalam sebuah organisasi tersebut yaitu dapat dilakukan dengan cara memberikan arahan atau penjelasan mengenai peraturan yang telah dibuat. Hal tersebut bertujuan supaya pegawai mengetahui lebih dalam terhadap peraturan yang telah ditetapkan dalam circle organisasi tersebut. Dimana setiap pegawai diharapkan harus mematuhi dan menjalankan peraturan sesuai dengan prosedur yang ada. Dengan adanya arahan ini diharapkan dapat meningkatkan kedisiplinan kerja, serta dapat meminimalisir adanya miss komunikasi antara atasan dengan pegawai mengenai peraturan yang berlaku.

Terdapat pula upaya lain yang juga bisa meningkatkan tingkat kedisiplinan kerja pegawai dalam organisasi, yaitu memberikan sebuah tindakan secara tegas dalam mengontrol atau memonitor tindakan kedisiplinan kerja. Tindakan tegas tersebut ditujukan kepada pegawai yang ketahuan secara kasat mata melakukan tindak pelanggaran kedisiplinan kerja, seperti : melanggar aturan atau melakukan kesalahan-kesalahan yang lain. Dimana setiap pegawai yang telah melakukan pelanggaran terhadap kedisiplinan kerja, akan dikenakan sanksi atau hukuman. Sanksi tersebut dapat berupa sanksi teguran, sanksi tertulis, penurunan jabatan, denda, mutasi, dsb. Pemberian sanksi tersebut sesuai dengan kesalahan yang telah diperbuat atau dilanggar. Hal tersebut diterapkan secara tegas dengan tujuan supaya dapat memberikan efek yang jera terhadap pegawai, serta agar pegawai tidak melakukan perbuatan yang semena-mena dalam menjalankan tugas tersebut.

Strategi dalam meningkatkan kedisiplinan kerja tersebut telah dijelaskan oleh Wursanto (2004:25) yang menyatakan bahwa kedisiplinan kerja tersebut yaitu sebuah keadaan yang dapat mengakibatkan ataupun dapat memberikan sebuah dorongan kepada pegawai, untuk melakukan serta 
menjalanankan suatu kegiatan yang diberikan yang sesuai dengan peraturan atau prosedur yang ada dalam organisasi tersebut. Melihat pentinganya kedisiplinan kerja dalam organisasi, maka perlu adanya penegasan supaya bisa meningkatkan kinerja pegawai. Dengan demikian, dapat dikatakan bahwa kedisiplinan kerja merupakan factor penunjang yang ada dalam diri pegawai untuk meningkatkan kinerja pegawai.

Pemantauan secara tegas mengenai kedisiplinan kerja ini harus dilakukan dan dilaksankan secara benar dan perlu keawasan. Karena ketika kedisiplinan kerja dilaksanakan secara baik sesuai dengan proseedur yang ada, maka kinerja yang dihasilkan juga akan meningkat atau meroket. Namun, jika tingkat kedisiplinan dalam organisasi tersebut buruk atau tidak dilaksanankan sesuai dengan standard yang ada, maka kinerja pegawai yang dihasilkan juga akan menurun. Oleh karena itu, kedisiplinan harus dan wajib ditingkatkan dengan sendirinya, terkhusus untuk ASN yang notabennya sebagai apartur negara (Hafid, 2018).

\section{Dampak Motivasi Kerja Terhadap Kinerja}

Motivasi kerja dinilai memiliki dampak yang sangat signifikan terhadap kinerja ASN. Menurut Hasibuan (2005) menjelaskan bahwa setiap manusia merupakan mahkluk yang social dan selalu memiliki keinganan. Dan keinginan tersebut berlanjut secara terus-menerus sampai kapan pun. Hal tersebut dapat menjadi motivasi seseorang untuk selalu berusaha dalam mencapai keinginan tersebut. Oleh karena itu, motivasi kerja sangat diperlukan untuk dorongan supaya dapat meningkatkan kinerja ASN dan mencapai keinginan tersebut (Murti \& Srimulyani, 2013).

Kadarisman berpendapat bahwa motivasi kerja memiliki sebuah makna yaitu suatu proses pemenuhan dorongan yang diberikan untuk pegawai, yang menyebabkan pegawai tersebut dapat bekerja secara maksimal serta tanpa adanya suatu paksaan dari siapa pun. Dalam sebuah organisasi atau instansi, susunan atau draft program-program tersebut dapat berjalan mulus ketika pegawai yang bekerja sudak melakukan atau menjalankan tugasnya dengan baik dan sesuai perintah.

Tujuan dari adanya pemberian sebuah motivasi kepada pegawai tersebut yaitu untuk memberikan stimulus dan penyemangat dalam melaksankan tugas. Sehingga kinerja yang dihasilkan juga akan memuaskan. Hal tersebut bisa dilakukan dengan cara meningkatkan pepuasan pegawai yang ada dalam instansi atau organisasi, menjaga hubungan baik dengan karyawan, menjaga kestabilan kepada karyawan, serta meningkatkan suasana kerja yang kondusif dan nyaman (Aldi \& Susanti, 2019).

Terdapat Sembilan indicator yang dapat mengukur motivasi kerja terhadap kinerja pegawai, diantaranya adalah : prestasi kerja yang ada, pekerjaan dari ASN itu sendiri, pengembangan diri individu, adanya pengakuan, kebijakan perusahaan yang efektif, korelasi terhadap rekan kerja, system keamanan kerja, hubungan yang baik dengan atasan, serta gaji. Melihat dari kesembilan itu tadi dapat mengukur motivasi kerja seseorang, yang nantinya berdampak pada tingkat kinerja karyawan. Oleh karena itu, cara atau langkah motivasi terhadap pegawai juga harus diperhatikan. Semakin baik cara memotivasi terhadap pegawai, maka tingkat kinerja yang ditimbulkan juga akan baik (Juniantara \& Riana, 2015).

Jika ditinjau dari teori Samsudin (2010:281) yang memaparkan bahwa motivasi merupakan suatu proses yang dapat mempengaruhi seseorang dalam menjalankan tugas yang telah ditentukan. Pemberian motivasi kerja dari atasan terhadap pegawai sangat diperlukan. Karena hal tersebut dapat meningkatkan kinerja pegawai ASN (Wahyudi \& Tupti, 2019). Oleh karena itu, atasan diharapkan dapat memberikan support kepada pegawai agar selalu konsisten dalam menjalankan tugasnya. Hal tersebut perlu dilakukan dan diterapkan supaya hasil kinerja dapat maksimal dan sesuai dengan harapan.

\section{Indiscipliner}

Indiscipliner merupakan sebuah pelanggaran kedisiplinan yang dilakukan terhadap aturanaturan yang telah ditetapkan. Adapun pelanggaran kedisiplinan yang sering dilakukan oleh ASN diantaranya adalah :

1. Melakukan pelanggaran peraturan perundang-undangan yang telah ditetapkan.

Dalam hal ini ASN yang melakukan pelanggaran peraturan UU dikarenakan karena minimnya pengetahuan tentang peraturan yang sudah ada. Melihat hal tersebut, pemerintahan 
harus mengeluarkan dan memberikan kebijakan-kebijakan secara tegas serta menuntut ASN untuk memahami lebih dalam mengenai peraturan atau prosedur yang ada.

2. Tugas kedinasan yang diberikan tidak dilaksanakan secara baik

Tugas yang telah diberikan merupakan bentuk sebuah kepercayaan yang seharusnya dikerjakan dengan penuh tanggung jawab. Namun hal ini sering disalahgunakan oleh ASN.

3. ASN melanggar jam kerja dan batas kehadiran.

Sesuai dengan ketentuan yang ada, jam kerja ASN selama satu minggu yaitu kurang lebih 37,5 jam. Namun ada juga ASN yang terkadang datang terlambat dan pulang sebelum waktunya. Bahkan ada juga yang sampai tidak masuk kerja melebihi batas ketentuan.

4. Dalam melaksanakan tugas tidak bisa memenuhi target yang telah ditentukan.

Target kerja merupakan sebuah pencapaian yang harus dilewati oleh ASN dalam melaksanakan tugasnya. Walaupun berat, namun hal ini sudah menjadi tanggungan dan harus dilaksanakan sesuai dengan apa yang diminta oleh atasan.

Factor yang dapat menyebabkan ASN melakukan pelanggaran yakni kurangnya informasi mengenai peraturan yang berlaku, minimnya tingkat kesadaran ASN dalam menjalankan tugas, kurangnya sikap tegas dari atasan kepada pegawai, serta kurang tegasnya penegakan terhadap pelanggaran kedisiplinan kerja.

Memilih pemimpin atau atasan yang tegas sangat diperlukan. Karena jika atasan mempunyai kebijakan yang tegas, maka tindakan pelanggaran kedisiplinan kerja dalam circle organisasi tersebut juga akan menurun. Selain itu penerapan sanksi-sanksi terhadap pelanggraan kedisiplinan juga harus ditegakkan dan tidak pandang bulu. Karena jika sanksi tersebut hanya dibuat dan tidak diterapkan, maka tingkat pelanggaran kedisiplinan juga akan meningkat, dimana yang nantinya juga dapat berpengaruh terhadap kinerja pegawai ASN (Sandiani et al., 2020).

\section{Simpulan dan Saran}

Penerapan kedisiplanan kerja perlu diperhatikan dalam sebuah cicrle organisasi. Penerapan tersebut dapat berbentuk seperti memberikan arahan atau penjelasan mengenai peraturan yang ada dalam lingkup organisasi tersebut. Hal ini bertujuan untuk menghindari kesalahpahaman antara pegawai dengan atasan. Adapun jika dalam melakukan sebuah pekerjaan, ditemukan seorang ASN yang melakukan pelanggaran seperti yang ada di Gunung Kidul. Maka atasan harus memberikan sebuah punishment yang sesuai dengan prosedur yang telah dilakukan. Pemberian punishment tersebut bisa berupa teguran atau sampai penurunan jabatan, sesuai dengan pelanggaran yang dilakukan. Hal ini bertujuan supaya memberikan efek jera kepada pelaku pelanggaran kedisiplinan kerja.

Begitu juga dengan motivasi kerja yang mempunyai dampak bagi kinerja ASN. Motivasi kerja tersebut dapat berupa pemberian reward kepada pegawai yang telah melakukan kinerjanya secara baik, pemberian fasilitas kerja yang memadai, dll. Oleh karena itu, atasan diharapkan dapat memberikan support kepada pegawai agar selalu konsisten dalam menjalankan tugas yang telah diberikan. Hal tersebut perlu dilakukan dan diterapkan supaya hasil kinerja dapat maksimal dan sesuai dengan harapan.

Adapun jenis indiscipliner yang sering dilakukan oleh ASN diantaranya adalah: melakukan pelanggaran peraturan perundang-undangan yang telah ditetapkan, tidak melaksanakan tugas kedinasan yang diberikan secara baik, ditemukan juga ASN melanggar jam kerja dan batas kehadiran, serta ASN tidak bisa memenuhi target tugas yang telah ditentukan oleh instansi. Hal tersebut dapat terjadi karena kurangnya pemberian sebuah informasi mengenai peraturan yang berlaku dan minimnya tingkat kesadaran ASN dalam menjalankan tugas,

Dari fenomena yang terjadi, diperlukan penegakan lebih tegas dalam menangani pegawai yang melakukan pelanggaran kedisiplinan kerja. Kemudian pengawasan terhadap kinerja pegawai juga perlu dipantau atau dilakukan secara berkala, dengan tujuan untuk mengurangi adanya pegawai yang melakukan pelanggaran kerja. Dan juga penerapan atau pemberian sanksi yang ketat, namun tetap sesuai dengan prosedur yang ada juga diperlu di apply tanpa memandang bulu. Karena dengan hal itu dapat meminimalisir pelanggaran kedisiplinan kerja khususnya pada ASN.

\section{Daftar Pustaka}

Aldi, Y., \& Susanti, F. (2019). Pengaruh Stress Kerja Dan Motivasi Kerja Terhadap Prestasi Kerja 
Karyawan Pada Pt. Frisian Flag Indonesia Wilayah Padang. https://doi.org/10.31227/osf.io/et4rn

Amiruddin. (2019). Pengaruh Etos Kerja, Disiplin dan Motivasi terhadap Kinerja Pegawai pada Dinas Perindustrian dan Perdagangan Kabupaten Biak Numfor (p. 120).

Danial, \& Warsiah. (2009). Metode Penulisan Karya Ilmiah. Laboratorium Pendidikan Kewarganegaraan UPI.

Haeli. (2018). DIKLAT PRAJABATAN CPNSD TENAGA HONORER K2/FORMASI KHUSUS ANGKATAN X LINGKUP PEMERINTAH KABUPATEN/KOTA SE-NUSA TENGGARA BARAT TAHUN 2018.

Hafid, H. (2018). Pengaruh Kompetensi, Kepemimpinan Dan Disiplin Kerja Terhadap Kinerja Pegawai Pada Samsat Polewali Mandar. Development Research of Management: Jurnal Manajemen, 13(2), 286-310.

Juniantara, I. W., \& Riana, I. G. (2015). Pengaruh Motivasi dan Kepuasan Kerja terhadap Kinerja Karyawan Koperasi di Denpasar. E-Jurnal Ekonomi Dan Bisnis, 09(4), 611-628.

Kurniawan, Harry, H. (2019). Effect of Work Discipline and Work Environment on Employee Performance with Work Motivation as an Intervening Variable in Department of Tourism , Youth and Sport of Padang District. Archives of Business Research, 7(7), 88-101.

Munadjat, B. M., Tumanggor, M., \& Oktrima, B. (2019). Pengaruh Kedisiplinan Kerja Terhadap Kinerja Karyawan Pada Pt. Subur Makmur Sentosa Cabang Cikupa Tangerang. JURNAL SeMaRaK, 2(1), 64-69. https://doi.org/10.32493/smk.v2i1.2666

Murti, H., \& Srimulyani, V. A. (2013). Pengaruh Motivasi Terhadap Kinerja Pegawai Dengan Variabel Pemediasi Kepuasaan Kerja Pada Pdam Kota Madiun. JRMA Jurnal Riset Manajemen Dan Akuntansi, 1(1), 10-17.

Mustika, M. M., \& Susanti, F. (2019). Pengaruh Sanksi, Reward Dan Pengembangan Sumber Daya Manusia Terhadap Disiplin Kerja Pegawai Pada Dinas Pekerjaan Umum Dan Penataan Ruang Kabupaten Dharmasraya. https://doi.org/10.31219/osf.io/d8b4a

Rosmaini, \& Tanjung, H. (2019). Pengaruh Kompetensi, Motivasi Dan Kepuasan Kerja Terhadap Kinerja Pegawai. Maneggio: Jurnal Ilmiah Magister Manajemen, 2(1), 1-15. https://doi.org/10.30596/maneggio.v2i1.3366

Sandiani, N. L., Suryawan, I. G. B., \& Widiati, I. A. P. (2020). Penegakan Sanksi Terhadap Aparatur Sipil Negara yang Melakukan Pelanggaran Disiplin di Lingkungan Pemerintah Kota Denpasar. Jurnal Interpretasi Hukum, 1(1), 196-203. https://doi.org/10.22225/juinhum.1.1.2210.196-203

Suprajang, A. R. dan S. E. (2017). Analisis Kedisiplinan Kerja dan Lingkungan Kerja terhadap Kinerja pada Karyawan PT Griya Asri Mandiri Blitar. Jurnal Penelitian Manajemen Terapan (PENATARAN), Vol. 2, 49-56. file:///C:/Users/ASUS/Downloads/315-Article Text-460-1-10-20171013.pdf

Tumilaar, B. R. (2015). the Effect of Discipline, Leadership, and Motivation on Employee Performance At Bpjs Ketenagakerjaan Sulut. Jurnal Riset Ekonomi, Manajemen, Bisnis Dan Akuntansi, 3(2), 787797.

Wahyudi, W. D., \& Tupti, Z. (2019). Pengaruh Budaya Organisasi, Motivasi dan Kepuasan Kerja Terhadap Kinerja. Maneggio: Jurnal Ilmiah Magister Manajemen, 2(1), 31-44. https://doi.org/10.30596/maneggio.v2i1.3363 